\title{
Uji Performansi Mesin A/C Split 1 PK Akibat Pengaruh Variasi Jarak Instalasi Outdoor-Unit Terhadap Dinding
}

\author{
Triaji Pangripto Pramudantoro ${ }^{1}$ \\ ${ }^{1}$ Jurusan Teknik Reverigerasi dan Tata Udara, Politeknik Negeri Bandung, Indonesia \\ email : triajipangripto@ polban.ac.id
}

\begin{abstract}
Abstrak
Mesin Jenis A/C split adalah mesin pendingin ruangan dengan kapasitas yang relatif kecil sehingga banyak digunakan sebagai alat pendingin ruangan rumah tangga, apartemen atau ruangan kantor. Seringkali ditemui pemasangan outdoor unit yang secara sembarangan dan tidak memperhatikan aspek performansinya, sehingga mesin menjadi kurang dingin, temperatur kondensasi naik, tekanan kerja kompresor meningkat, akibatnya konsumsi daya listrik akan meningkat. Tujuan dari penelitian ini adalah untuk mengkaji bagaimana pengaruhnya terhadap performansi mesin A/C split apabila penempatan outdoor unitnya divariasikan jaraknya terhadap dinding, sehingga dari hasil kajian tersebut akan diperoleh jarak minimum pemasangan outdoor unit terhadap dinding agar dihasilkan performansi mesin A/C split yang optimum. Metoda yang dilakukan adalah dengan memasang sistem A/C split dimana pemasangan outdoor unit dapat digeser-geser jaraknya terhadap dinding, dimulai dari jarak outdoor unit 5 $\mathrm{cm}$ terhadap dinding, selanjutnya berturut turut $10 \mathrm{~cm}, 15 \mathrm{~cm}, 20 \mathrm{~cm}, 25 \mathrm{~cm}$ dan $30 \mathrm{~cm}$. Dari hasil kajian ini menunjukkan performansi yang baik adalah setelah jarak pemasangan outdoor unit terhadap dinding sekitar $20 \mathrm{~cm}$ dengan hasil chilling time lebih cepat (40 menit), tekanan discharge menurun (12\%), kerja kompresi menurun (18\%), efek refrigerasi meningkat (9\%) dan nilai COP meningkat 30\%. Sehingga dapat dikatakan jarak yang baik untuk pemasangan outdoor unit terhadap dinding adalah minimum $20 \mathrm{~cm}$.
\end{abstract}

Kata Kunci A/C Split; outdoor unit; Instalasi A/C split

\section{PENDAHULUAN}

Sistem Refrigerasi atau Tata udara jenis kompresi uap pada dasarnya adalah sebuah sistem dengan teori kesetimbangan energi, dimana energi yang diserap di evaporator yang berasal dari produk akan dibuang di kondenser melalui media pendingin air atau udara. Permasalahan yang sering timbul adalah penempatan outdoor unit pada $\mathrm{A} / \mathrm{C}$ split yang terlalu dekat terhadap dinding yang dapat mengakibatkan proses pelepasan kalor ke lingkungan menjadi terhambat. Hal ini tentunya akan sangat berpengaruh terhadap performansi mesin A/C tersebut diantaranya adalah temperatur yang ingin dicapai menjadi terganggu, tekanan kerja dapat meningkat sehingga mesin $\mathrm{A} / \mathrm{C}$ menjadi panas dan kemungkinan menjadi sering trip. Dalam persoalan demikian maka perlu ada batas jarak minimum antara outdoor unit mesin $\mathrm{A} / \mathrm{C}$ split terhadap dinding dengan tujuan untuk mendapatkan hasil performansi mesin $\mathrm{A} / \mathrm{C}$ split yang optimum sehingga diharapkan akan terjadi pula penghematan energi. Misalnya apabila pembuangan kalor di outdoor unit tidak terhambat maka ada kemungkinan temperatur ruangan yang didinginkan akan lebih cepat tercapai sehingga mesin $\mathrm{A} / \mathrm{C}$ split tersebut akan berada dalam posisi lebih sering cut-off. Demikian pula kerja kompresornya akan menjadi lebih ringan karena beban pendinginan yang dapat dibuang ke lingkungan lebih lancar. Setelah diperoleh hasil jarak minimum pemasangan outdoor unit terhadap dinding yang optimum tersebut maka nilai besaran jarak tersebut diharapkan dapat digunakan sebagai referensi bagi yang membutuhkanya.

\section{TINJAUAN PUSTAKA}

Pertumbuhan pasar mesin tata udara di negara berkembang mencapai $14 \%$ per tahun (Daikin Corp., 2015). Besarnya perkembangan pasar mesin tata udara dan refrigerasi tentu harus diantisipasi dengan penyediaan sumber energi dan/atau rekayasa produk yang hemat energi. Di Indonesia, tingkat penggunaan energi listrik untuk pengkondisian udara mencapai kurang lebih 50\% (Karyono dan Bahri, 2005). Karena harga energi semakin mahal, maka diperlukan usaha atau rekayasa yang tepat untuk menghemat penggunaan energi. Susilawati dan Andriyanto (2017) telah melakukan pengujian pengaruh kecepatan putar kipas kondenser antara $60 \%$ hingga $100 \%$ dan mengahsilkan pengaruh yang terjadi pada mesin A/C diantaranya: kenaikan tekanan discharge, kenaikan temperatur udara keluaran kondenser, kenaikan temperatur udara keluaran evaporator, kenaikan konsumsi daya listrik, dan penurunan kapasitas pendinginan. Pembuangan energi kalor di kondenser dengan metoda sub-cooling telah terbukti dapat meningkatkan efek refrigerasi dan performansi A/C split (Kasni Sumeru, Triaji Pangripto dan Andriyanto S, 2018)

Prinsip kerja AC split tersebut sangat sederhana dimana refrigeran yang diisikan ke dalam sistem akan dikompresi dan disirkulasikan oleh kompresor melalui kondenser untuk dilepaskan kalornya ke lingkungan, selanjutnya refrigeran akan berubah fasa menjadi fasa cair dan diekspansikan oleh pipa kapiler menuju ke evaporator sehingga tekanan dan temperaturnya turun. Temperatur yang rendah di dalam pipa evaporator tersebut selanjutnya dihembuskan ke dalam ruangan sehingga terasa sejuk. Sementara refrigeran yang berada di dalam evaporator akan berubah fasa menjadi fasa uap karena telah menyerap kalor dari ruangan yang didinginkan, selanjutnya refrigeran mengalir menuju ke saluran hisap kompresor untuk disirkulasikan kembali. Demikian selanjutnya proses tersebut berulang secara terus menerus. Gambar skematik AC split terlihat seperti pada Gambar 2.1. Pada gambar tersebut terlihat bahwa posisi evaporator berada di atas dan umumnya dipasang di dalam ruangan maka sering disebut sebagai indoor-unit, sedangkan kompresor, kondenser dan alat ekspansi 
berada di dalam satu wadah yang biasanya dipasang di luar ruangan maka sering disebut sebagai outdoor-unit.

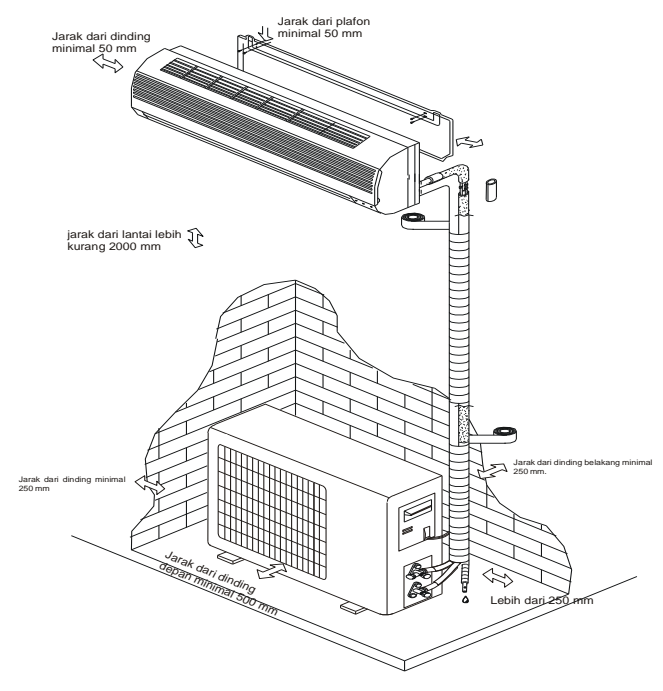

Gambar 2.1 A/C Split

Proses-proses pendinginan yang terjadi pada sistem refrigerasi kompresi uap pada umumnya adalah proses kompresi, proses kondensasi, proses ekspansi dan proses evaporasi (Arora, 2001; ASHRAE, 2013)

Proses tersebut dapat dijelaskan dan digambarkan dalam bentuk diagram Mollier sebagai berikut.

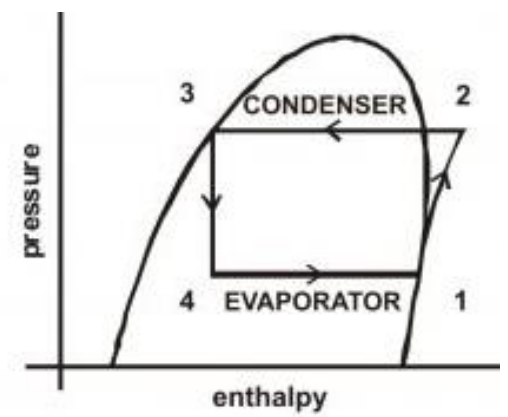

Gambar 2.2 Diagram P-h siklus refrigerasi kompresi uap sederhana

Dari gambar 2-2 dapat dijelaskan sebagai berikut.

1-2 Proses Kompresi

Refrigeran masuk ke kompresor dalam keadaan uap jenuh dengan temperatur rendah dan tekanan rendah. Refrigeran yang masuk kompresor dikompresi sehingga menjadi uap superheat. Refrigeran yang keluar dari kompresor dalam keadaan temperatur tinggi dan tekanan tinggi.

Besarnya kerja yang dilakukan kompresor dapat dihitung menggunakan Persamaan-1.

$$
Q_{W}=\dot{m}\left(h_{2}-h_{1}\right)
$$

Dengan,

$$
\begin{aligned}
& \text { Qw = Kerja Kompresi }(\mathrm{kW}) \\
& \text { = Laju aliran massa refrigeran }(\mathrm{kg} / \mathrm{s}) \\
& \mathrm{h} 1=\text { Entalpi refrigeran masuk kompresor }(\mathrm{kJ} / \mathrm{kg}) \\
& \mathrm{h} 2=\text { Entalpi refrigeran keluar kompresor }(\mathrm{kJ} / \mathrm{kg})
\end{aligned}
$$

Atau

Kerja spesifik dapat dihitung menggunakan Persamaan -2.

$q_{W}=\left(h_{2}-h_{1}\right)$

2-3 Proses Kondensasi

Di kondenser refrigeran melepaskan kalor ke lingkungan sehingga terjadi penurunan temperatur sampai batas uap jenuh, setelah itu refrigeran berubah fasa dari uap menjadi cair jenuh. Proses ini terjadi dalam keadaan tekanan konstan (isobar) dan besar kalor yang dilepaskan di kondenser atau heat rejection dapat dihitung menggunakan Persamaan-3.

$$
Q_{C}=\dot{m}\left(h_{2}-h_{3}\right)
$$

Dengan,

$\mathrm{Qc}=$ Besarnya kalor yang dilepaskan di kondenser $(\mathrm{kW})$

$=$ Laju aliran massa refrigeran $(\mathrm{kg} / \mathrm{s})$

$\mathrm{h} 2=$ Entalpi refrigeran masuk kondenser $(\mathrm{kJ} / \mathrm{kg})$

$\mathrm{h} 3=$ Entalpi refrigeran keluar kondenser $(\mathrm{kJ} / \mathrm{kg})$

Atau

Kalor spesifik yang dilepas dapat dihitung menggunakan Persamaan-4.

$$
q_{c}=\left(h_{2}-h_{3}\right)
$$

\section{3-4 Proses Ekspansi}

Pada proses ini refrigeran masuk ke dalam alat ekspansi dan mengalami penurunan tekanan sehingga temperaturnya pun mengalami penurunan. Dalam hal ini refrigeran tidak mengalami penambahan atau pengurangan entalpi tetapi terjadi drop tekanan dan penurunan temperatur sehingga proses ini berlangsung dalam kondisi entalpi konstan (iso-entalphy) yaitu: h3 = h4

Dengan,

$\mathrm{h} 3=$ Entalpi refrigeran masuk ekspansi $(\mathrm{kJ} / \mathrm{kg})$

$\mathrm{h} 4=$ Entalpi refrigeran keluar ekspansi $(\mathrm{kJ} / \mathrm{kg})$

Umumnya refrigeran yang masuk dalam keadaan cair jenuh dan setelah diekspansi refrigeran akan keluar dalam keadaan fasa campuran namun dominan cair.

\section{4-1 Proses Evaporasi}

Proses ini terjadi pada tekanan konstan (isobar) dan temperatur konstan (isothermal). Refrigeran yang keluar dari alat ekspansi masuk ke evaporator lalu menyerap kalor dari bahan atau media yang akan didinginkan. Refrigeran yang ada di evaporator menguap sehingga fasanya berubah dari fasa campuran menjadi fasa uap seluruhnya pada tekanan dan temperatur yang rendah.

Refrigeran yang keluar dari evaporator dalam bentuk uap jenuh dan besar kalor yang diserap oleh evaporator disebut beban pendinginan atau kapasitas pendinginan. Kalor yang diserap oleh evaporator dapat dihitung menggunakan Persamaan-5.

$$
\begin{aligned}
& Q_{e}=\dot{m}\left(h_{1}-h_{4}\right) \\
& \text { Dengan, } \\
& \text { Qe = Beban Pendinginan }(\mathrm{kW}) \\
& \quad=\text { Laju aliran massa refrigeran }(\mathrm{kg} / \mathrm{s}) \\
& \mathrm{h} 1=\text { Entalpi refrigeran masuk evaporator }(\mathrm{kJ} / \mathrm{kg}) \\
& \mathrm{h} 4=\text { Entalpi refrigeran keluar evaporator }(\mathrm{kJ} / \mathrm{kg})
\end{aligned}
$$

Penarikan kalor spesifik disebut efek refrigerasi, dapat dihitung menggunakan Persamaan-6.

$$
q_{e}=\left(h_{1}-h_{4}\right)
$$

Berdasarkan besaran-besaran di atas maka akan dihasilkan siklus refrigerasi kompresi uap standar atau yang biasa disebut dengan COP (Coefficient of Performance) sistem. COP diperoleh dari perbandingan antara efek refrigerasi terhadap kerja kompresi.

COP aktual adalah perbandingan efek refrigerasi terhadap kerja kompresi. COP aktual dapat dihitung menggunakan Persamaan-7.

$$
C O P_{\text {actual }}=\frac{\text { Efek Refrigerasi }}{\text { Kerja Kompresi }}=\frac{q_{e}}{q_{w}}
$$

Nilai COP tersebut akan sangat dipengaruhi oleh kerja kompresi dan efek pendingianan yang terjadi pada mesin AC. Apabila kerja kompresi meningkat karena temperatur kerja naik, maka nilai COP 
akan menurun demikian pula jika efek refrigerasinya menurun walau kerja kompresinya stabil maka otomatis nilai COP akan menurun pula. Penurunan efek refrigerasi bisa terjadi akibat dari kenaikan tekanan atau temperatur di kondenser (Arora, 2001; ASHRAE, 2013).

Dalam kasus instalasi pemasangan outdoor unit $\mathrm{A} / \mathrm{C}$ split maka sangat dianjurkan antara dinding banguan terhadap permukaan outdoor unit mesin $\mathrm{A} / \mathrm{C}$ split memiliki jarak yang cukup agar proses terjadinya pelepasan kalor oleh kondenser ke lingkungan dapat berjalan dengan baik, dengan harapan tidak terjadi kenaikan tekanan discharge, kenaikan temperatur udara keluaran kondenser, kenaikan temperatur udara keluaran evaporator, kenaikan konsumsi daya listrik, dan penurunan kapasitas pendinginan (Susilawati dan Andriyanto S, 2017).

\section{METODOLOGI PENELITIAN}

Penelitian ini dilakukan pada mesin A/C split berkapasitas 1(satu) PK dengan jenis refrigeran R410. Mesin A/C dipasang pada ruangan seperti layaknya ruangan pada umumnya dengan ukuran panjang kali lebar sebesar 4 x 4 meter. Outdoor- unit dipasang di luar ruangan dengan dipasangi roda pada bagian bawahnya sehingga mudah untuk digeser-geser saat diperlukan pengambilan data apabila jarak yang divariasikan harus berganti. Parameter yang diukur diantaranya:

1. Tekanan discharge

2. Tekanan suction

3. Temperatur kondenser

4. Temperatur keluaran dari kondenser

5. Temperatur suction

6. Temperatur Ruangan

7. Temperatur lingkungan

Kegiatan penelitian yang dilaksanakan dapat dilihat pada Gambar 3.1 diagram alir sebagai berikut:

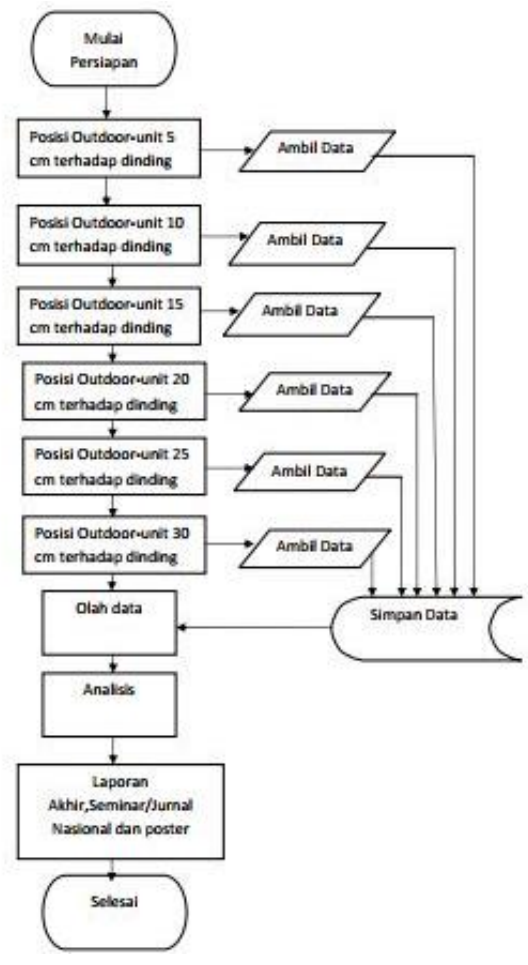

Gambar 3.1 Diagram alir Penelitian

\section{HASIL DAN PEMBAHASAN}

\section{IV.1 Laju Pendinginan}

Gambar 4.1 menunjukkan grafik laju penurunan temperatur yang terjadi di dalam ruangan uji dimana biasanya berupa ruang untuk hunian. Temperatur awal di dalam ruangan berkisar $27 \mathrm{oC}$ yang selanjutnya dilakukan pengujian penurunan temperatur hingga 18oC. Pada Gambar 4.1 Laju penurunan temperatur tampak jelas dipengaruhi oleh jarak outdoor unit terhadap dinding, semakin dekat jarak outdoor unit terhadap dinding maka menyebabkan semakin lama temperatur ruangan dapat tercapai,

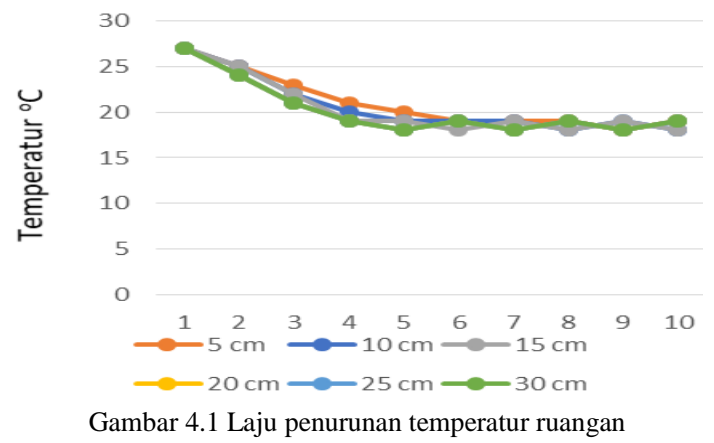

Pada Gambar 4.1 tampak saat jarak outdoor unit terhadap dinding adalah $5 \mathrm{~cm}$ maka temperatur ruangan tercapai pada menit ke 90 sementara saat jarak outdoor unit terhadap dinding adalah $20 \mathrm{~cm}$ maka temperatur ruangan dapat tercapai pada nenit ke 50, demikian juga ternyata terjadi hal yang sama saat jarak outdoor unit digeser menjauh terhadap dinding menghasilkan laju pendinginan yang tidak jauh berbeda dengan saat jarak outdoor unit berkisar sekitar 20 $\mathrm{cm}$ terhadap dinding. Artinya dapat dikatakan bahwa jarak pemasangan outdoor unit terhadap dinding yang baik adalah minimal sekitar $20 \mathrm{~cm}$ dengan selisih waktu chilling time sekitar 40 menit.

\section{IV.2 Tekanan discharge}

Jarak pemasangan outdoor unit yang semakin dekat terhadap dinding akan menyebakan tekanan kerja mesin meningkat terutama pada tekanan discharge seperti yang dapat dilihat pada Gambar 4.2.

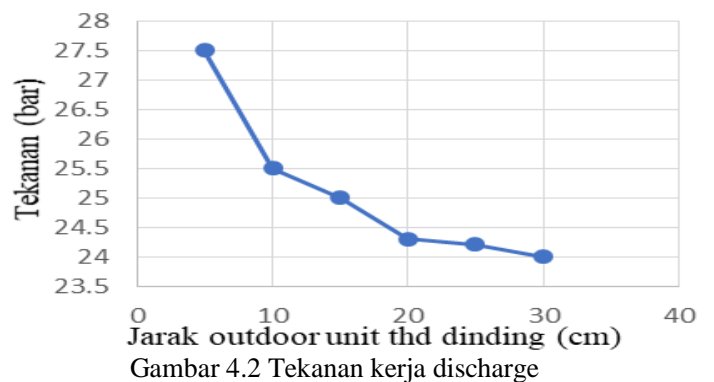

Pada Gambar 4.2 tampak dengan jelas saat jarak pemasangan outdoor unit berkisar $5 \mathrm{~cm}$ terhadap dinding maka menghasilkan tekanan kerja sekitar 27,5 bar namun seiring dengan digesernya posisi outdoor unit menjauh dari dinding maka tekanan kerja discharge tampak menurun sejak posisi pemasangan outdoor unit berjarak $20 \mathrm{~cm}$ dengan tekanan kerja 24,3 bar hingga 24 bar yaitu saat jarak outdoor unit berkisar $30 \mathrm{~cm}$ atau dapat dikatakan terjadi selisih perbedaan tekanan sekitar $12 \%$. Kenaikan tekanan ini dapat terjadi karena laju aliran udara panas di kondenser yang seharusnya dapat dibuang ke lingkungan menjadi terhambat karena adanya dinding penghalang. 


\section{IV.3 Kerja kompresi}

Seiring dengan kenaikan tekanan yang terjadi pada sisi discharge yang disebabkan karena pembuangan kalor yang terhambat oleh dinding, maka kerja kompresi pun akan meningkat seperti yang ditunjukkan pada Gambar 4.3 sebagai berikut.

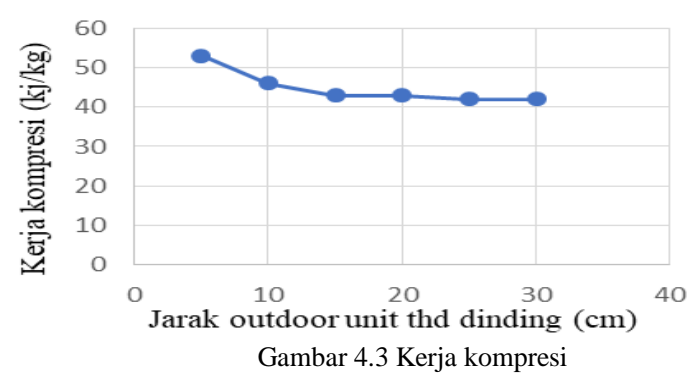

Pada Gambar 4.3 Kerja kompresi tampak relatif cukup tinggi saat jarak outdoor unit terhadap dinding berkisar $5 \mathrm{~cm}$ dengan nilai kerja spesifik sebesar $53 \mathrm{kj} / \mathrm{kg}$, namun setelah jarak outdoor unit digeser menjauh terhadap dinding maka tampak kerja kompresinya menurun hingga mencapai yang terendah adalah 43 $\mathrm{kj} / \mathrm{kg}$, atau dapat dikatakan terjadi penghematan energi sekitar 10 $\mathrm{kj} / \mathrm{kg}$ atau $18 \%$. Dengan demikian dapat dikatakan bahwa penempatan outdoor unit yang telalu dekat terhadap dinding akan menyebabkan kompresor bekerja lebih berat dan sebaliknya jika jarak pemasangan outdoor unit lebih renggang terhadap dinding maka kerja kompresi menjadi lebih ringan.

\section{IV.44.4 Efek refrigerasi}

Kenaikan tekanan dan temperatur yang terjadi pada kondenser akibat terhalang oleh dinding dapat menyebabkan laju pelepasan kalor dari refrigeran ke lingkungan menjadi terhambat dan berakibat terhadap penurunan efek refrigerasinya seperti yang dapat dilihat pada Gambar 4.4 berikut ini.

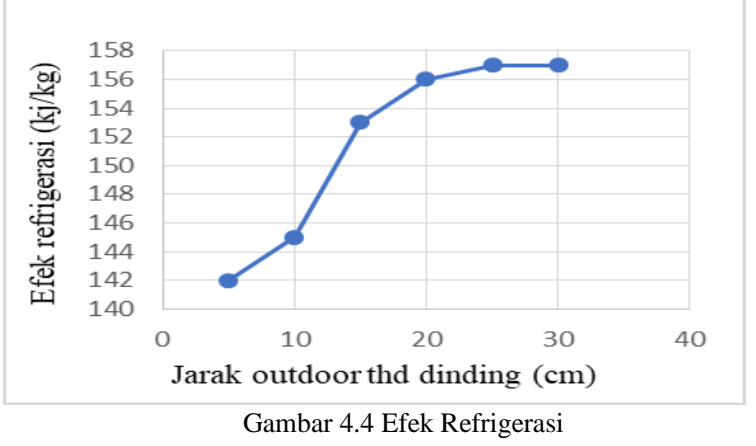

Efek refrigerasi adalah nilai kalor spesifik yang terjadi di evaporator dimana kalor spesifik tersebut menunjukkan besarnya energi yang dapat diserap oleh refrigeran yang mengalir di dalam pipa evaporator. Semakin besar nilai efek refrigerasinya maka dapat dikatakan semakin baik evaporator tersebut dalam menyerap kalor. Pada Gambar 4.4 tampak bahwa ketika jarak pemasangan outdoor unit terhadap dinding sekitar $5 \mathrm{~cm}$, dapat menghasilkan nilai efek refrigerasi sebesar $143 \mathrm{kj} / \mathrm{kg}$ namun seiring dengan digesernya jarak pemasangan outdoor unit menjauh dari dinding hingga $25 \mathrm{~cm}$ tampak nilai efek refrigerasinya meningkat hingga $157 \mathrm{kj} / \mathrm{kg}$ atau ada kenaikan sekitar 9\%.

\section{IV.5 Ceficient of Performance}

Coefisien of Performance (COP) adalah salah satu indikator prestasi suatu mesin refrigerasi atau A/C. Semakin tinggi nilai
COP yang dimiliki oleh sebuah mesin refrigerasi atau A/C dapat diartikan bahwa mesin tersebut makin baik.

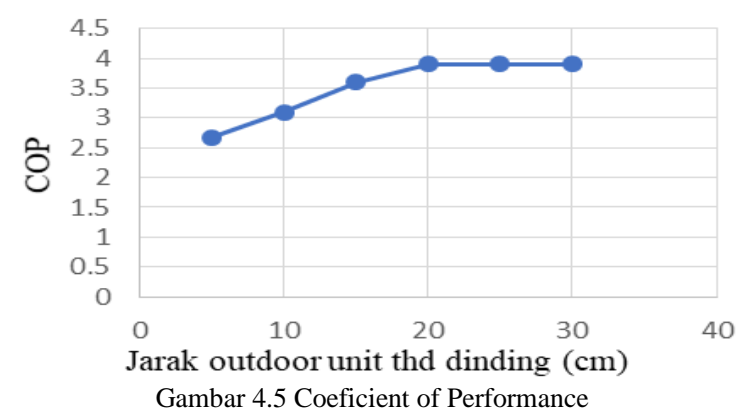

COP sangat dipengaruhi oleh tekanan dan temperatur kerja yang terjadi di kondenser dan kerja kompresi. Seperti yang telah dijelaskan sebelumnya bahwa laju aliran udara pada kondenser yang terhalangi atau terhambat oleh dinding, dapat menyebabkan kenaikan tekanan kondensasi dan berakibat pula terhadap kenaikan kerja kompresi. Kenaikan tekanan kondenser berakibat terhadap penurunan efek refigerasi, sehingga kemampuan evaporator untuk menyerap kalor menjadi menurun pula. Akibatnya COP dari sistem A/C tersebut menjadi rendah. Demikian sebaliknya apabila pelepasan kalor yang terjadi di kondenser lancar maka berakibat nilai efek refrigerasinya meningkat dan kerja kompresi menjadi lebih ringan sehingga nilai COP menjadi lebih tinggi. Seperti yang dapat dilihat pada Gambar 4.5 ketika jarak antara outdoor unit terhadap dinding adalah $5 \mathrm{~cm}$ memiliki nilai COP 2,7, sementara ketika jarak pemasangan outdoor unit berjarak $20 \mathrm{~cm}$ atau lebih, maka terjadi kenaikan COP hingga mencapai 3,9. Sehingga dapat dikatakan ada kenaikan nilai COP hingga 30\%

\section{KESIMPULAN}

Dari hasil kajian didapatkan bahwa jarak pemasangan outdoor unit apabila digeser dari $5 \mathrm{~cm}$ terhadap dinding menjadi $20 \mathrm{~cm}$, menghasilkan laju pendinginan lebih cepat 40 menit, tekanan kondensasi lebih rendah $12 \%$, kerja kompresi lebih rendah $18 \%$, efek refrigerasi meningkat 9\% dan COP meningkat hingga $30 \%$. Sehingga dapat dikatakan bahwa jarak minimum untuk menghasilkan performansi A/C split yang cukup baik adalah $20 \mathrm{~cm}$.

\section{DAFTAR PUSTAKA}

[1] Arora, CP, Refrigeration and Air Conditioning, Tata McGraw-Hill Publishing Co. Ltd, New Delhi,2001.

[2] ASHRAE, ASHRAE Handbook of Fundamental, American Society of Heating, Refrigerating and Air Conditioning Engineers, Atlanta, 2013

[3] http://engineeringbuilding.blogspot.com/2011/02/menentukan-tempatpemasangan-ac-split.html, diakses pada 21 April 2020

[4] https://cvastro.com/tips-memasang-ac-split.htm, diakses pada 21 April 2020

[5] Karyono,T.H \& G.Bahri, Energy efficient strategies for JSX building in Jakarta, Indonesia, International conference "Passive and low energy cooling for the built Environment", May 2005, Santorini, Greece.

[6] Kasni Sumeru, Triaji Pangripto dan Andriyanto S., Experimental investigation on the performance of residential air conditioning system using water condensate for subcooling. MATEC Web of Conferences 197, 08002 (2018) https://doi.org/10.1051/matecconf/201819708002 AASEC 2018

[7] Susilawati dan Andriyanto. Seminar Nasional RTII-STTN, "Kajian pengaruh kecepatan putar kipas kondenser terhadap konsumsi energi dan kapasitas pendingin mesin tata udara", Yogyakarta, 2017

[8] www.daikin.comabout/why_daikin/rise/Increase in Air Conditioning Demand in Emerging Countries, Diakses pada 8 April 2015. 